\section{Salivary Immunoglobulins in Individuals with Common Variable Immunodeficiency}

Karin Sá Fernandes ${ }^{1}$, Michella Bezerra Lima ${ }^{1}$, Cíntia de Paula Martins', Maria Cristina dos-Santos ${ }^{2}$, Fabio Daumas Nunes ${ }^{1}$, Cristina Maria Kokron ${ }^{3}$, Marina Gallottini ${ }^{1}$

\begin{abstract}
Oral manifestations of common variable immunodeficiency (CVID) are rare, have rarely been studied and have given controversial results. There are few data about $\lg A, \lg G$, and $\operatorname{lgM}$ antibody salivary levels in the literature, and there are few papers about the clinical impact of antibody deficiencies and CVID on the oral health of such patients. The aim of this study was to measure serum and salivary $\lg \mathrm{A}, \lg \mathrm{G}$, and $\lg \mathrm{M}$ levels in CVID participants and controls, and to associate immunoglobulin levels with caries and periodontal disease. This was a case-control study involving 51 CVID individuals and 50 healthy controls. All participants underwent examination for dental caries and periodontal disease. Blood and whole saliva samples were collected on the same day of the oral examination. Serum $\lg A$, $\lg \mathrm{M}$, and $\lg \mathrm{G}$ levels were measured by turbidimetry and salivary $\lg \mathrm{A}, \lg \mathrm{M}$, and $\lg \mathrm{G}$ titers were assessed by enzyme-linked immunosorbent assay. Incidences of caries and gingivitis were significantly higher in the CVID group than in the control group $(p<0.05)$. Salivary and blood $\lg \mathrm{A}$ and $\lg \mathrm{M}$ titers were significantly reduced in the CVID group, but there was no association of salivary immunoglobulin levels with periodontal disease or with caries incidence ( $p>0.05$ for both). Although CVID was associated with increased susceptibility to caries and gingivitis, it was not associated with low salivary levels of $\lg \mathrm{A}$ and $\lg \mathrm{M}$.
\end{abstract}

'Stomatology Department, Dental School of São Paulo, USP Universidade de São Paulo, SP, Brazil ${ }^{2}$ Department of Parasitology, Institute of Biological Sciences, UFAM - Universidade Federal do Amazonas, Manaus, AM, Brazil ${ }^{3}$ Laboratory of Clinical Immunology and Allergy, LIM-60, Hospital das Clínicas, USP - Universidade de São Paulo, São Paulo, SP, Brazil

Correspondence: Karin Sá Fernandes, Av. Prof. Lineu Prestes, 2227, 05508-000 São Paulo, SP, Brasil. Tel.: +55-11-3091-7902. e-mail: karinsf@gmail.com

\section{Introduction}

Common variable immunodeficiency (CVID) is a relatively frequent form of primary immunodeficiency, compared to other human immune defects, and affects about 1 in 25,000 persons. It is characterized by low serum immunoglobulin $(\mathrm{lg})$ levels, resulting in increased susceptibility to bacterial infections (especially in the respiratory and gastrointestinal tracts), autoimmune diseases, lymphoproliferative disorders and granulomatous diseases, as well as poor response to immunization protocols $(1,2)$. The primary phenotypic defect is a failure in B cell differentiation, resulting in impaired secretion of $\lg A, \lg G$ and $\lg M(2)$. Diagnosis is difficult because of the infrequent incidence, high clinical variability of CVID and lack of specific laboratory tests, and is generally established years after the onset of the disease (3-5).

Oral manifestations of CVID were seldom studied and provided controversial results. Engstrom, in 1992, observed that the CVID patients were higher on the periodontal index severity scale compared to the controls. Among 23 individuals, 34.8\% showed oral lichenoid lesions with Wickman's striae. Sculy et al. $(6,7)$ studied 15 subjects with CVID and found pseudomembranous candidiasis, recurrent aphthous ulcer and enamel hypoplasia among 11. Kirstilä et al. $(6,8)$ showed no remarkable differences in dental caries and periodontal diseases.
There are few data about $\lg \mathrm{A}, \lg \mathrm{G}$ and $\lg \mathrm{M}$ antibody salivary levels in the literature. There are reports claiming that $\lg A, \lg G$ and $\lg M$ antibodies can affect the oral microbiota by interfering with adherence or by inhibiting bacterial metabolism (9). Little is known regarding the clinical impact of antibody deficiencies and CVID on the oral health of such patients.

The aim of this study was to measure serum and salivary $\lg \mathrm{A}, \lg \mathrm{G}$ and $\lg \mathrm{M}$ levels in a large sample of CVID patients comparing with a control group and to look for possible association of Ig salivary levels with periodontal disease and caries. Secondarily, it was sought to determine the oral health status of individuals with CVID.

\section{Material and Methods}

This was a case-control study. The study sample consisted of 101 individuals, divided into two groups: the CVID group, comprising 51 individuals with CVID and the control group, comprising 50 individuals without CVID. The CVID patients were selected among those treated at the outpatient clinic of the Department of Allergy and Clinical Immunology of the Medical School of Universidade de São Paulo. The controls were chosen among individuals with no immunologic disorders who were under routine dental treatment at the dental clinic of the Universidade 
de São Paulo Dental School. The study was approved by the research ethics committees of the involved institutions and all participants signed a written informed consent.

The authors collected data on demographic characteristics, alcohol use, tobacco use, illicit drug use, medication use and self-reported comorbidities, as well as medical and dental history. All participants were clinically examined by a single trained dentist with a mouth mirror, a dental explorer and a periodontal probe under artificial light. Dental caries status was assessed by the decayed, missing and filled teeth (DMFT) index. Periodontal status was assessed by bleeding on probing, the community periodontal index of treatment needs and the simplified periodontal screening and recording index. All soft tissue lesions were examined and biopsy was performed when required. Blood samples were collected on the same day of the oral examination. The blood samples were analyzed by the clinical analysis laboratory of the Medical School of Universidade de São Paulo and the quantification of serum immunoglobulins was determined using turbidimetry.

Unstimulated whole saliva samples were collected in the morning, at least $1 \mathrm{~h}$ after breakfast, with the subject sitting upright in a comfortable position in a quiet, isolated $\approx$ room. The saliva was centrifuged at 7,500 rpm for 10 min at $4{ }^{\circ} \mathrm{C}$; the supernatant fraction was transferred to an Eppendorf tube containing a buffer solution $(1 \mathrm{mM}$ ethylenediaminetetraacetic acid and $10 \mathrm{mM}$ Tris- $\mathrm{HCl}$ ) and a protease inhibitor, stored at $-80^{\circ} \mathrm{C}$.

Salivary $\lg \mathrm{A}, \lg \mathrm{M}$ and $\lg \mathrm{G}$ titers were measured by enzyme-linked immunosorbent assay. All experiments were performed in duplicate. One hundred $\mu \mathrm{L}$ of saliva from each individual were placed in 96-well plates (MecLab, Jacareí, SP, Brazil), serially diluted $(1: 125,1: 250,1: 500,1: 1,000,1: 2,000$, $1: 4,000,1: 8,000$, and $1: 16,000$ for $\lg A ; 1: 50,1: 100,1: 200$, $1: 400,1: 800,1: 1,600,1: 3,200$, and 1:6,400 for $\lg \mathrm{G} ;$ and $1: 100,1: 200,1: 400,1: 800,1: 1,600,1: 3,200,1: 6,400$, and $1: 12,800$ for $\lg \mathrm{M})$. The plates remained under continuous agitation for $2 \mathrm{~h}$ at room temperature. Subsequently, the plates were washed once with phosphate-buffered saline (PBS; $10 \mathrm{mM}$ sodium phosphate buffer and $100 \mathrm{mM}$ $\mathrm{NaCl} ; \mathrm{pH}$ 7.2), blocked with $5 \%$ skim milk (Molico ${ }^{\oplus}$; Nestlé S.A., Vevey, Switzerland) dissolved in PBS and incubated under continuous agitation for $1 \mathrm{~h}$ at room temperature. Then the plates were washed once with PBS (pH 7.2) and incubated with anti-human IgA ( $\alpha$-chain; Pierce Chemical Co., Rockford, IL, USA), anti-human IgG $(\mathrm{H}+\mathrm{L}$; Pierce Chemical) and anti-human IgM ( $\mathrm{F} c \mu$ fragment specific; Pierce Chemical). The conjugates were diluted at 1:1,000 in PBS ( $\mathrm{pH}$ 7.2). After $45 \mathrm{~min}$, the plates were washed six times with PBS (pH 7.2) and the antibody-conjugate reactions were developed with $2 \mathrm{mg}$ of o-Phenylenediamine dihydrochloride (Dako, Glostrup, Denmark) diluted in 11
$\mathrm{mL}$ citrate buffer (10 mM citric acid, $\mathrm{pH} \mathrm{6}$, and $10 \mathrm{mM}$ sodium citrate, $\mathrm{pH} 6$ ) in the presence of $0.015 \%$ hydrogen peroxide. Absorbance was measured at $405 \mathrm{~nm}$ with an absorbance microplate reader (ELX800; BioTek Instruments, Inc., Winooski, VT, USA) in order to determine the endpoint titer for each whole saliva sample.

Statistical analysis was performed with the GraphPad Prism software, version 5.0 for Windows (GraphPad Software, San Diego, CA, USA). The level of statistical significance was set at $p<0.05$. Fisher's exact test was used in order to compare the CVID and control groups regarding salivary Ig levels and determine whether those levels were associated with the presence of caries, periodontal disease or other oral lesions. Additionally were compared the use of antibiotics and periodontal disease in the CVID group.

\section{Results}

Among the 51 individuals in the CVID group, 30 (59\%) were male and 51 (100\%) described themselves as White. The median age was 34 years (range 15-77 years). One (1.96\%) of the 51 individuals in the CVID group reported tobacco use, and none reported chronic alcohol abuse. Of the 50 individuals in the control group, $35(70 \%)$ were female. In addition, 34 (66\%) described themselves as White, 2 (4\%) described themselves as Afro-descendent and 14 (28\%) described themselves as being Asian. The median age was 24.5 years (range 20-51 years). Among the 50 controls, $3(6 \%)$ reported tobacco use and none reported chronic alcohol abuse.

The mean age of symptomatic CVID onset was 22 years. All the individuals in the CVID group were monthly treated with intravenous IgG replacement therapy. At the time of examination, 27 of the 51 CVID patients were using antibiotics (penicillin by 16 ; azithromycin by 4 ; trimethoprim-sulfamethoxazole, by 5 , and ciprofloxacin, by 2). None of the controls used antibiotics.

The incidence of caries and gingivitis was higher in the CVID group than in the control group $(p<0.05)$, as was the DMFT index (10.51 vs. 4.68). Enamel hypoplasia, dry mouth, geographic tongue, traumatic ulcer and recurrent aphthous ulcer were observed in individuals from both groups, and there was no difference in rates of these disorders between the study and control groups. Table 1 summarizes the oral health conditions of the participants.

The single tobacco user of the CVID group and the 3 tobacco users from control group did not present gingivitis nor periodontitis.

Out of the 27 CVID patients using antibiotics, 6 had gingivitis and 1 had periodontitis; among the 24 who were not, 6 had gingivitis and 3 had periodontitis. Out of the 50 controls, $3(6 \%)$ were diagnosed with gingivitis and $1(2 \%)$ was diagnosed with periodontitis. No statistical correlation 
was found between the use of antibiotics and the absence of periodontal disease in those patients ( $p>0.05)$.

According to the laboratory value references, among the 51 individuals in the CVID group, 48 showed low serum IgA levels $(<40 \mathrm{mg} / \mathrm{dL}), 40$ showed low serum IgM levels $(<40 \mathrm{mg} / \mathrm{dL})$, and 25 showed low serum IgG levels $(<650$ $\mathrm{mg} / \mathrm{dL}$ ). Table 2 shows the levels of serum $\lg A, \lg G$ and $\lg M$ in the CVID group.

Regarding salivary Ig levels, IgA and IgM titers were lower in the CVID group than in the control group, whereas $\lg \mathrm{G}$ titers were the same in both groups. Most of the participants from control group (49/50; 98\%) exhibited salivary IgA titers above $1 / 500$, and most of the participants with CVID $(37 / 51 ; 72.5 \%)$ showed salivary IgA titers under $1 / 250$, which means low levels of IgA. All of them (37/51)

Table 1. Oral health problems in the common variable immunodeficiency and control groups

\begin{tabular}{lccc}
\hline Oral manifestations & $\begin{array}{c}\text { Number of } \\
\text { individuals } \\
\text { from SG } \\
\text { presenting the } \\
\text { manifestation } \\
51(100 \%)\end{array}$ & $\begin{array}{c}\text { Number of } \\
\text { individuals } \\
\text { from CG } \\
\text { presenting the } \\
\text { manifestation } \\
50(100 \%)\end{array}$ & $\mathrm{p}$ value \\
\hline Gingivitis* & $12(23.5 \%)$ & $3(6 \%)$ & $\mathrm{p}<0.05$ \\
Caries* & $10(19,6 \%)$ & $1(2 \%)$ & $\mathrm{p}<0.05$ \\
Enamel hypoplasia & $9(17.64 \%)$ & $4(8 \%)$ & $\mathrm{p}=0.2343$ \\
Periodontitis & $4(7.84 \%)$ & $1(2 \%)$ & $\mathrm{p}=$ \\
$\begin{array}{l}\text { Moderate pocket } \\
\text { (PD 4-5 mm) }\end{array}$ & 4 & 0 & 0.3624 \\
$\begin{array}{l}\text { Deep pocket } \\
\text { (PD > 6mm) }\end{array}$ & 0 & 0 & $\mathrm{p}=1$ \\
Dry mouth & $1(1.96 \%)$ & 0 & $\mathrm{p}=$ \\
Geographic tongue & $2(3.92 \%)$ & 0.4950 \\
Traumatic ulcer & $1(1.96 \%)$ & 0 & $\mathrm{p}=1$ \\
RAU & $1(1.96 \%)$ & 0 & $\mathrm{p}=1$ \\
\hline
\end{tabular}

$\mathrm{PD}=$ Probing depth, RAU = recurrent aphtous ulcer. *Statistically significant difference between the SG and CG.

Table 2. Levels of serum immunoglobulins (IgA, IgG, and IgM) in individuals with common variable immunodeficiency

\begin{tabular}{lc}
\hline Serum immunoglobulins & CVID individuals $(\mathrm{n}=51)$ \\
\hline IgA & 48 \\
Low value $(<40 \mathrm{mg} / \mathrm{dL})$ & 3 \\
Normal value $(40-382 \mathrm{mg} / \mathrm{dL})$ & \\
IgG & 25 \\
Low value $(<650 \mathrm{mg} / \mathrm{dL})$ & 26 \\
Normal value $(650-1538 \mathrm{mg} / \mathrm{dL})$ & \\
IgM & 40 \\
Low value $(<40 \mathrm{mg} / \mathrm{dL})$ & 11 \\
Normal value $(40-171 \mathrm{mg} / \mathrm{dL})$ & \\
\hline
\end{tabular}

also showed serum IgA below the reference value $(<40 \mathrm{mg} /$ $\mathrm{dL})$. Most participants from the control (42/50) and study groups (38/51) showed IgG titers from $1 / 400$ to $1 / 3.200$. Ten individuals from study group (10/50) and 2 from control group (2/51) exhibited higher levels of salivary IgG titers $(1: 6.400,>1: 12800)$. All control participants showed salivary IgM titers above $1 / 400$ and the study group participants presented variable values for salivary lgM titers, most of them under $1 / 400$. Figures $1 \mathrm{~A}, 1 \mathrm{~B}$ e $1 \mathrm{C}$ show salivary $\lg \mathrm{A}$, $\lg \mathrm{G}$ and $\lg \mathrm{M}$ levels in the CVID and control groups.

In the present study, among participants from CVID group, no statistical significance was found between
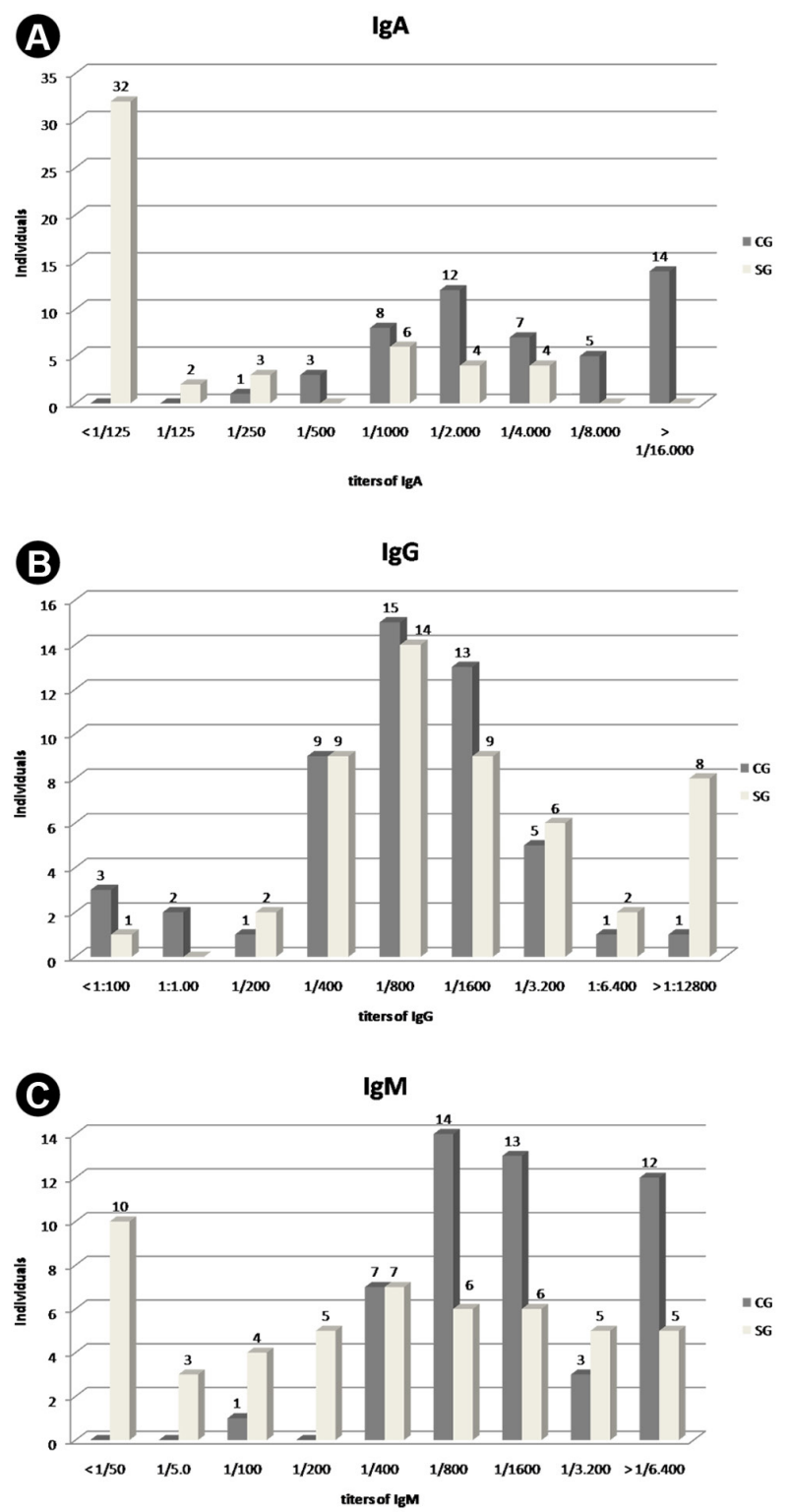

Figure 1. A: Salivary levels of IgA in the common variable immunodeficiency (CVID) and control groups. B: Salivary levels of IgG in the common variable immunodeficiency (CVID) and control groups. C: Salivary levels of IgM in the common variable immunodeficiency (CVID) and control groups. 
salivary immunoglobulins levels and caries $(p>0.05)$ or between Ig levels and periodontal diseases $(p>0.05)$.

\section{Discussion}

Despite the accumulated knowledge regarding oral microbial ecology and the role of Igs, there are few data regarding the impact of antibody deficiencies on oral health or the effect of poor oral health on the well-being of CVID patients. Unlike serum Igs, most salivary Igs do not act as opsonizing agents (10). It is known that $\lg G, \lg M$ and $\lg A$ antibodies may influence the oral microbiota by interfering with adherence or by inhibiting bacterial metabolism (10).

The obtained results showed that gingivitis and caries were more common in the CVID group than in the control group. Among the 51 CVID patients, 12 (23.5\%) had gingivitis and $10(19.6 \%)$ had caries. Serum IgA and IgM levels were lower in the CVID group than in the control group, as were the salivary $\lg \mathrm{A}$ and $\lg \mathrm{M}$ levels. However, salivary IgG levels were higher in the CVID group than in the control group, probably because of the compensatory adjustment. Nevertheless, there was no significant association between reduced salivary IgA and IgM levels with caries and periodontal disease. Many of the patients with reduced salivary $\lg \mathrm{A}$ and $\lg \mathrm{M}$ levels exhibited good oral health. On the other hand, some of the CVID patients presenting caries and periodontal disease showed normal $\lg \mathrm{A}$ and $\lg \mathrm{M}$ salivary levels. Simultaneous occurrence of these two aspects (caries and periodontal disease and reduced salivary $\lg A$ and $\lg M$ occurrence), could be demonstrated but not the causal relation between them.

Finding more caries and periodontal disease in the study group confirmed the study hypothesis. However, it was expected to find lower levels of salivary IgA and salivary $\lg \mathrm{M}$ in patients affected by these diseases. The fact that this correlation was not found could be partly explained by the fact that this is a cross-sectional study, measuring immunoglobulins just once.

Norhagen Engström and Engström (11) demonstrated the impact of tobacco on salivary immunoglobulins, showing that the $\lg A$ is increased and $\lg G$ and $\lg M$ is reduced in saliva of the tobacco users. In the conducted study, this analysis could not be performed because only one participant from study group, was a tobacco user. The only tobacco user patient presented reduced salivary $\lg \mathrm{A}$ and salivary $\lg \mathrm{M}$, but no periodontal diseases.

In a previousstudy by this group (12), were assessed the oral manifestationsof hypogammaglobulinemia in 100 individuals diagnosed with CVID, X-linked agammaglobulinemia; hyper-IgM syndrome; hypogammaglobulinemia without a defined cause; secondary hypogammaglobulinemia; severe combined immunodeficiency; and specific antibody deficiency. The results showed that individuals with hypogammaglobulinemia presented lower prevalence of dental caries and periodontal disease, compared with a control group. On the other hand, the results showed higher prevalence of enamel hypoplasia and complaints of dry mouth. Most of the CVID patients from the present study were the same included in this previous study. The obtained results showed that CVID individuals presented more caries and periodontal disease than controls and no immunomediated mucosal lesions nor opportunistic oral infections..

Engstrom et al. (6) and Kirstila et al. (8) investigatedexclusively CVID patients (15 and 23 patients, respectively) and found no increased incidence of caries or periodontal disease in those patients compared with healthy individuals. These results agree with those of other authors $(7,13)$, who reported an increased risk of caries and periodontal disease in 12 and 15 CVID patients, respectively.

Although intravenous Ig replacement therapy was shown to be safe and effective in CVID patients, infections are common in such patients and the choice of an appropriate antibiotic therapy is indicated in the onset of acute infection. Although $52.94 \%$ of the 51 CVID patients in the present study were under broad-spectrum antibiotics treatment at the time of clinical dental examination, the statistical analysis revealed no correlation between the use of antibiotics and the absence of periodontal disease in those patients.

Even though CVID was found to be associated with increased susceptibility to caries and periodontal disease, in the present study oral health was generally preserved in all CVID patients. Nevertheless, preventive oral health care is essential because CVID patients are at risk of bacterial aspiration and, consequently, bacterial pneumonia and are more likely to develop respiratory infections. The dental plaque is an important reservoir of potential respiratory bacterial pathogens, including Staphylococcus aureus, Pseudomonas aeruginosa, Acinetobacter spp. and enteric bacteria $(14,15)$.

To the authors' knowledge, this was the first study involving a large sample of CVID patients and determining their salivary Ig levels, as well as assessing their oral health. Reduced salivary $\lg A$ and $\lg M$ levels were found accompanying reduced serum $\lg A$ and $\lg M$ levels. But the statistical correlation test could not be performed, because the salivary and plasmatic Igs were measured using different techniques.

No statistical significance was found between the reduced salivary $\lg \mathrm{A}$ and $\lg \mathrm{M}$ levels with caries or periodontal disease. Many of those with reduced salivary $\operatorname{lgA}$ and IgM levels showed good oral health. Some of the CVID participants investigated in the present study were found to be more likely to have caries and periodontal 
disease in spite of their Ig levels. Anyway, careful oral health monitoring is essential because there are various respiratory pathogens in the oral cavity and CVID patients are more likely to develop respiratory infections.

\section{Resumo}

As manifestações orais em pacientes com imunodeficiência comum variável (ICV) têm sido pouco estudadas e com resultados variados. Há escassos dados na literatura sobre os niveis de $\lg A$, $\lg G$ e $\lg M$ na saliva, e pouco se sabe sobre o impacto clínico da deficiência destes anticorpos sobre a saúde bucal de pacientes com ICV. 0 objetivo deste estudo foi medir os niveis séricos e salivares de IgA, lgG e lgM em indivíduos com ICV e controles, e associar os niveis de imunoglobulinas com cárie e doença periodontal. Este foi um estudo de caso-controle, envolvendo 51 indivíduos ICV e 50 controles saudáveis. Todos os participantes foram examinados para cárie e doença periodontal. As amostras de sangue e saliva foram coletadas no mesmo dia do exame intraoral. Os niveis de $\lg \mathrm{A}$, $\lg \mathrm{M}$ e $\lg \mathrm{G}$ foram medidos por turbidimetria, e os titulos salivares de IgA, IgM e lgG foram avaliados através método imunoenzimático (ELISA). As incidências de cáries e gengivite foram significativamente maiores no grupo ICV do que no grupo controle $(p<0,05)$. Os niveis de IgA e IgM salivares e no sangue foram significativamente reduzidos no grupo ICV, porém não houve associação dos niveis de imunoglobulina salivar com doença periodontal ou com a incidência de cárie ( $p>0,05$ para ambos). Embora ICV foi associado com um aumento da susceptibilidade à cárie $\mathrm{e}$ gengivite, não estava associado com baixos niveis salivares de $\lg \mathrm{A}$ e $\lg \mathrm{M}$.

\section{References}

1. Rosen FS, Cooper MD, Wedgwood RJ. The primary immunodeficiencies. N Engl J Med 1995;333:431-440.

2. Di Renzo M, Pasqui AL, Auteri A. Common variable immunodeficiency: a review. Clin Exp Med 2004;3:211-217.

3. Conley $M E$, Notarangelo LD, Etzioni A. Diagnostic criteria for primary immunodeficiencies. Representing PAGID (Pan-American Group for Immunodeficiency) and ESID (European Society for Immunodeficiencies). Clin Immunol 1999;93:190-197.
4. Cunningham-Rundles $\mathrm{C}$, Bodian $\mathrm{C}$. Common variable immunodeficiency: clinical and immunological features of 248 patients. Clin Immunol 1999;92:34-48.

5. Kokron CM, Errante PR, Barros MT, Baracho GV, Camargo MM, Kalil J, et al.. Clinical and laboratory aspects of common variable immunodeficiency. An Acad Bras Cienc 2004;76:707-726.

6. Engström GN, Engström PE, Hammarström L, Smith Cl. Oral conditions in individuals with selective immunoglobulin A deficiency and common variable immunodeficiency. J Periodontol 1992;63:984-989.

7. Scully C, Porter SR. Orofacial manifestations in primary immunodeficiencies: common variable immunodeficiencies. J Oral Pathol Med 1993;22:157-158.

8. Kirstilä V, Tenovuo J, Ruuskanen 0 , Nikoskelainen J, Irjala K, Vilja P. Salivary defense factors and oral health in patients with common variable immunodeficiency. J Clin Immunol 1994;14:229-236.

9. Smith DJ, van Houte J, Kent R, Taubman MA. Effect of antibody in gingival crevicular fluid on early colonization of exposed root surfaces by mutans streptococci. Oral Microbiol Immunol 1994;9:65-69.

10. Van Nieuw Amerongen A, Bolscher JG, Veerman EC. Salivary proteins: protective and diagnostic value in cariology? Caries Res 2004;38:247253.

11. Norhagen Engström G, Engström PE. Effects of tobacco smoking on salivary immunoglobulin levels in immunodeficiency. Eur J Oral Sci 1998;106:986-991.

12. Fernandes KS, Kokron CM, Barros MT, Kalil J, Gallottini M. Oral manifestations in patients with hypogammaglobulinemia. Oral Surg Oral Med Oral Pathol Oral Radiol 2012;114:e19-e24.

13. Cole MF, Arnold RR, Rhodes MJ, McGhee JR. Immune dysfunction and dental caries: a preliminary report. J Dent Res 1977;56:198-204.

14. Scannapieco FA, Stewart EM, Mylotte JM. Colonization of dental plaque by respiratory pathogens in medical intensive care patients. Crit Care Med 1992;20:740-745.

15. Scannapieco FA, Yu J, Raghavendran K, Vacanti A, Owens SI, Wood K, et al.. A randomized trial of chlorhexidine gluconate on oral bacterial pathogens in mechanically ventilated patients. Crit Care 2009;13:R117.

Received June 1, 2016 Accepted September 13, 2016 